\title{
Rozwiązania systemowe kształtujące rozwój Zintegrowanego Systemu Kwalifikacji w Polsce
}

DOI: 10.47050/65591814.192-214

Katarzyna Trawińska-Konador

W rozdziale przedstawiono rozwiązania Zintegrowanego Systemu Kwalifikacji (ZSK), wprowadzone ustawą o ZSK z 2015 r. Zmodernizowanie krajowego systemu kwalifikacji przez wdrożenie Polskiej Ramy Kwalifikacji (PRK) i Zintegrowanego Rejestru Kwalifikacji (ZRK) pozwala na integrację różnych obszarów edukacji, w których nadaje się kwalifikacje. Rozwiązania dotyczące tworzenia i nadawania cząstkowych kwalifikacji o charakterze zawodowym (tzw. kwalifikacji rynkowych) stanowią wysokiej jakości uzupełnienie i dopełnienie kwalifikacji zawodowych nadawanych w systemie szkolnym i sprawiają, że oferta edukacyjna jest bardziej dopasowana do wyzwań współczesnego rynku pracy. Drugim nowym instrumentem ZSK jest Zintegrowany Rejestr Kwalifikacji - baza danych zawierająca informacje o kwalifikacjach włączonych do ZSK wraz z informacjami dotyczącymi podmiotów je nadających oraz procedur zapewniania jakości.

Istotnym elementem ZSK, stanowiącym jego branżowy kontekst, są sektorowe ramy kwalifikacji wspierające kształcenie i szkolenie zawodowe. Rozwiązania systemowe wprowadzone Ustawą o Zintegrowanym Systemie Kwalifikacji spajają system kształcenia w Polsce, wspierając obywateli w uczeniu się przez całe życie i zdobywaniu kwalifikacji wysokiej jakości, potrzebnych na współczesnym rynku pracy.

\section{Słowa kluczowe:}

Zintegrowany System Kwalifikacji (ZSK)

Europejska Rama Kwalifikacji (ERK)

Polska Rama Kwalifikacji (PRK)

Sektorowa Rama Kwalifikacji (SRK) 


\section{System solutions shaping the development of the Integrated Qualifications System in Poland}

DOI: $10.47050 / 65591814.192-214$

Katarzyna Trawińska-Konador

The chapter presents the solutions of the Integrated Qualifications System (IQS), introduced by the Act on Integrated Qualifications System from 2015. Modernization of the national qualifications system by implementing the Polish Qualification Framework and the Integrated Qualifications Register (IQR) allows integration of various areas of education in which qualifications are obtained. Solutions related to the development and certification of partial vocational qualifications (so-called market qualifications) constitute a high-quality supplement and complement of professional qualifications given in the school system and make the educational offer more suited to the challenges of the modern labour market. The second new instrument of IQS is the Integrated Register of Qualifications, a database of qualifications included to the IQS, with information on the certification bodies or quality assurance and validation procedures.

An important element of IQS, constituting its professional context, are the sectoral qualifications frameworks supporting vocational education and training. wSystem solutions introduced by the Act on Integrated Qualifications System make the education system in Poland more coherent and support citizens in lifelong learning and acquiring highquality qualifications required by the modern labour market.

\section{Keywords:}

Integrated Qualifications System (IQS)

European Qualifications Framework (EQF)

Polish Qualifications Framework (PQF)

Sectoral Qualifications Framework (SQF) 


\section{Wprowadzenie}

Niniejszy rozdział został poświęcony Zintegrowanemu Systemowi Kwalifikacji (ZSK), który jest przede wszystkim zorientowany na wspieranie Polaków w uczeniu się w różnych formach i na różnych etapach życia. W kontekście tematu przewodniego niniejszej książki, jakim jest kształcenie zawodowe, warto bliżej przyjrzeć się rozwiązaniom mającym niejako stanowić integrator różnych obszarów edukacji, w których nadawane są kwalifikacje: systemowi kształcenia formalnego (ogólnego, zawodowego i wyższego) i pozaformalnego. Polska Rama Kwalifikacji (PRK), która swoim zasięgiem obejmuje wszystkie typy kwalifikacji nadawane w Polsce, jest narzędziem, które na poziomie krajowym i międzynarodowym może funkcjonować dzięki serii reform przeprowadzonych w systemie formalnym. Tworzenie kwalifikacji na podstawie efektów uczenia się, ich przenoszenie, walidacja i zapewnianie jakości w zgodzie z europejskimi standardami stało się częścią całego systemu edukacji formalnej (ogólnej, zawodowej i wyższej) jeszcze przed opracowaniem i przyjęciem PRK (Chłoń-Domińczak 2016). PRK jako podstawa Zintegrowanego Systemu Kwalifikacji stanowi wspólny układ odniesienia dla kwalifikacji nadawanych w Polsce. Drugim nowym instrumentem ZSK jest Zintegrowany Rejestr Kwalifikacji (ZRK), obejmujący te kwalifikacje, których jakość jest gwarantowana określonymi procedurami i nadzorowana przez konkretny podmiot. Wpisanie kwalifikacji do ZRK wiąże się z nadaniem jej poziomu. Schemat Zintegrowanego Systemu Kwalifikacji przedstawiony na rysunku 1 obejmuje układ powiązań między kluczowymi działaniami, dzięki którym osiąga się integrację polskiego systemu kwalifikacji oraz możliwe staje się wiarygodne odniesienie za pośrednictwem PRK kwalifikacji nadawanych w Polsce do Europejskiej Ramy Kwalifikacji. Rozwój ZSK stwarza większe możliwości identyfikowania, dokumentowania i potwierdzania efektów uczenia się osiąganych w ciągu całego życia. Dzięki „językowi efektów uczenia się", stanowiącemu wspólny mianownik dla kwalifikacji włączonych do ZSK (z obszaru edukacji formalnej: ogólnej, zawodowej i wyższej oraz z obszaru pozaformalnego), możliwe jest elastyczne podejście do systemu kształcenia i przenikanie się jego różnych ścieżek i form. Kwalifikacje zawodowe cząstkowe włączane do ZSK i umieszczone w rejestrze kwalifikacji (tzw. kwalifikacje rynkowe) stanowią wysokiej jakości uzupełnienie i dopełnienie kwalifikacji zawodowych nadawa- 
nych w systemie szkolnym i sprawiają, że oferta edukacyjna jest bardziej dopasowana do wyzwań współczesnego rynku pracy.

\section{Europejska Rama Kwalifikacji katalizatorem zmian na rzecz rozwoju systemów kwalifikacji w państwach czlonkowskich UE}

Szeroko pojęta edukacja, a w jej ramach kształcenie i szkolenie zawodowe należą do dziedzin, w których Unia Europejska (UE) ma kompetencje do wspierania, koordynowania lub uzupełniania działań państw członkowskich1.

Zgodnie z art. 166 TFUE „Unia urzeczywistnia politykę kształcenia zawodowego, która wspiera i uzupełnia działanie Państw Członkowskich, w pełni szanując odpowiedzialność Państw Członkowskich za treść i organizację kształcenia zawodowego"2.

Ważne miejsce w polityce edukacyjnej Unii Europejskiej mają działania na rzecz zapewniania porównywalności kwalifikacji nadawanych w poszczególnych państwach członkowskich UE, co powinno sprzyjać integracji rynku usług edukacyjnych, a przede wszystkim integracji rynku pracy. Instrumentami służącymi wdrażaniu tej polityki są m.in. Europejska Rama Kwalifikacji (ERK) oraz odnoszące się do niej krajowe ramy kwalifikacji (Ponikowska 2015) ${ }^{3}$.

Wspólne ramy odniesienia mają służyć jako instrument porównania kwalifikacji i ich poziomów w różnych krajowych systemach kwalifikacji, zarówno w kształceniu ogólnym i wyższym, jak i w kształceniu oraz szkoleniu zawodowym. Ma to poprawić przejrzystość, porównywalność i możliwość przenoszenia kwalifikacji obywateli między tymi krajami (Zalecenie Parlamentu Europejskiego... 2008, s. 1-16). Rozwój i wdrażanie krajowych ram kwalifikacji odnoszących się do Europejskiej Dz.Urz. UE 2009, C 290/01. koordynacji (open method of coordination), będącej międzyrządową metodą zarządzania w UE w wielu obszarach polityk (np. zatrudnienie czy polityka społeczna). Parlamentu Europejskiego i Rady z dnia 22 maja 2017 r. w sprawie europejskich ram kwalifikacji dla uczenia się przez całe życie uchylające zalecenie Parlamentu Europejskiego i Rady z dnia 23 kwietnia 2008 r. w sprawie ustanowienia europejskich ram kwalifikacji dla uczenia się przez całe życie. 
Ramy Kwalifikacji monitorowane jest regularnie od 2004 r. przez European Centre for the Development of Vocational Training (CEDEFOP) - Europejskie Centrum Rozwoju Kształcenia Zawodowego. Po niemal dekadzie od rozpoczęcia rozwijania i wdrażania ERK i krajowych systemów kwalifikacji opartych na krajowych ramach kwalifikacji w raporcie CEDEFOP z 2017 r. wskazuje się, że pod koniec 2017 r. 34 państwa, w tym także Polska, formalnie (na podstawie procesu referencyjnego) odniosły swoje krajowe ramy kwalifikacji do ERK4. Przewiduje się, że pozostałe kraje dopełnią procesu referencji w 2018 r. (National qualifications... 2018, s. 13-14).

Warto zwrócić uwagę, że ERK stanowi źródło inspiracji dla rozwoju krajowych, regionalnych i sektorowych (branżowych) ram kwalifikacji na całym świecie. Z roku na rok wzrasta liczba państw i regionów, które poszukują sposobów na powiązanie swoich ram kwalifikacji z ERK. Polska jest przykładem kraju, który zalecane rozwiązania europejskie potraktował jako szansę na zmodernizowanie niektórych elementów własnego krajowego systemu kwalifikacji. Odniesienie projektu PRK do ERK zostało przedstawione w raporcie referencyjnym przyjętym w 2013 r. przez Grupę Doradczą ds. ERK. W raporcie tym, oprócz samej PRK, przedstawiono przebieg i stan prac nad projektami innych rozwiązań mających na celu unowocześnienie krajowego systemu kwalifikacji w Polsce (Sławiński i in. 2013), w tym zmodernizowanie obszaru kwalifikacji nadawanych w systemie kształcenia pozaformalnego.

Opracowanie ramy kwalifikacji stanowiło tylko pierwszy krok na długiej drodze do zmodernizowania polskiego systemu kwalifikacji. Aby narzędzia takie jak PRK oraz ZRK mogły spełniać swoje funkcje, oparte na zasadach zapewniania jakości, konieczne było obudowanie ich mechanizmami i rozwiązaniami, które staną na straży jakości kwalifikacji nadawanych poza systemami oświaty i szkolnictwa wyższego. Przykładem może być stworzenie systemu jednolitych egzaminów zawodowych. W lipcu 2016 r. uruchomiono portal internetowy ZSK oraz ZRK. Od tego momentu rozpoczęło się stopniowe wdrażanie narzędzi ZSK określonych w ustawie.

Pozostałe państwa to: Austria, Belgia (Flandria i Walonia), Bułgaria, Chorwacja, Cypr, Czarnogóra, Czechy, Dania, Estonia, Finlandia, Francja, Grecja, Holandia, Islandia, Irlandia, Kosowo, Liechtenstein, Litwa, Luksemburg, Łotwa, Macedonia Północna, Malta, Niemcy, Norwegia, Portugalia, Słowacja, Słowenia, Szwajcaria, Szwecja, Turcja, Węgry, Wielka Brytania (Anglia, Szkocja i Walia) i Włochy. 
Istotą regulacji zawartych w ustawie o ZSK jest wdrożenie spójnych rozwiązań systemowych dotyczących kwalifikacji nadawanych poza systemami oświaty i szkolnictwa wyższego oraz większa integracja różnych obszarów, w których nadaje się kwalifikacje. Przyjęte regulacje mają przyczynić się do zwiększenia wiarygodności oraz zapewnienia porównywalności kwalifikacji nadawanych zarówno w Polsce, jak i za granicą oraz do poprawy dopasowania kompetencji pracowników do potrzeb rynku pracy, szczególnie w odniesieniu do kwalifikacji spoza systemów oświaty oraz szkolnictwa wyższego, tj. kwalifikacji rynkowych5.

Ustawa o ZSK określa następujące obszary:

1. zakres kwalifikacji włączonych do Zintegrowanego Systemu Kwalifikacji oraz cele Zintegrowanego Systemu Kwalifikacji;

2. Polską Ramę Kwalifikacji;

3. standardy opisywania kwalifikacji;

4. zasady przypisywania poziomów Polskiej Ramy Kwalifikacji do kwalifikacji;

5. zasady włączania kwalifikacji do Zintegrowanego Systemu Kwalifikacji;

6. zasady włączania Sektorowych Ram Kwalifikacji do Zintegrowanego Systemu Kwalifikacji;

7. wymogi dotyczące podmiotów przeprowadzających walidację i certyfikowanie oraz zasady uzyskiwania uprawnień do certyfikowania;

8. zasady zapewniania jakości walidacji i certyfikowania;

9. zasady nadzoru nad walidacją i certyfikowaniem;

10.Zintegrowany Rejestr Kwalifikacji;

11. koordynację funkcjonowania Zintegrowanego Systemu Kwalifikacji.

Zgodnie z Ustawą z dnia 22 grudnia 2015 r. o Zintegrowanym Systemie Kwalifikacji (art. 2 pkt 11) kwalifikacje rynkowe to kwalifikacje nieuregulowane przepisami prawa, których nadawanie odbywa się na zasadzie swobody działalności gospodarczej. Kwalifikacje rynkowe są to kwalifikacje wypracowane przez różne środowiska (organizacje społeczne, zrzeszenia, korporacje lub inne podmioty) na podstawie zgromadzonych przez nie doświadczeń. Wyraz "rynkowe” oznacza w tym przypadku, że kwalifikacje te powstały i funkcjonują na "wolnym rynku” kwalifikacji. Kwalifikacje rynkowe mogą, ale nie muszą być włączane do ZSK. O włączeniu decyduje minister właściwy dla kwalifikacji w odpowiedzi na inicjatywę zainteresowanego środowiska. Wszystkie kwalifikacje rynkowe włączone do ZSK są kwalifikacjami cząstkowymi. 
Ustawa nie określa wymogów walidacji i certyfikowania, zasad zapewniania jakości nadawania kwalifikacji oraz zasad nadzoru nad nadawaniem kwalifikacji w zakresie kwalifikacji uzyskiwanych w systemie oświaty oraz $\mathbf{w}$ systemie szkolnictwa wyższego. Tym samym kwalifikacje szkolne, a wśród nich również pochodzące ze szkolnictwa zawodowego, weszły do rejestru na mocy ustawy - automatycznie. Kilkustopniowa procedura włączania kwalifikacji do ZRK przewidziana jest dla pozostałych kwalifikacji, tych pozaformalnych - czyli rynkowych.

Rysunek 1. Zintergrowany System Kwalifikacji

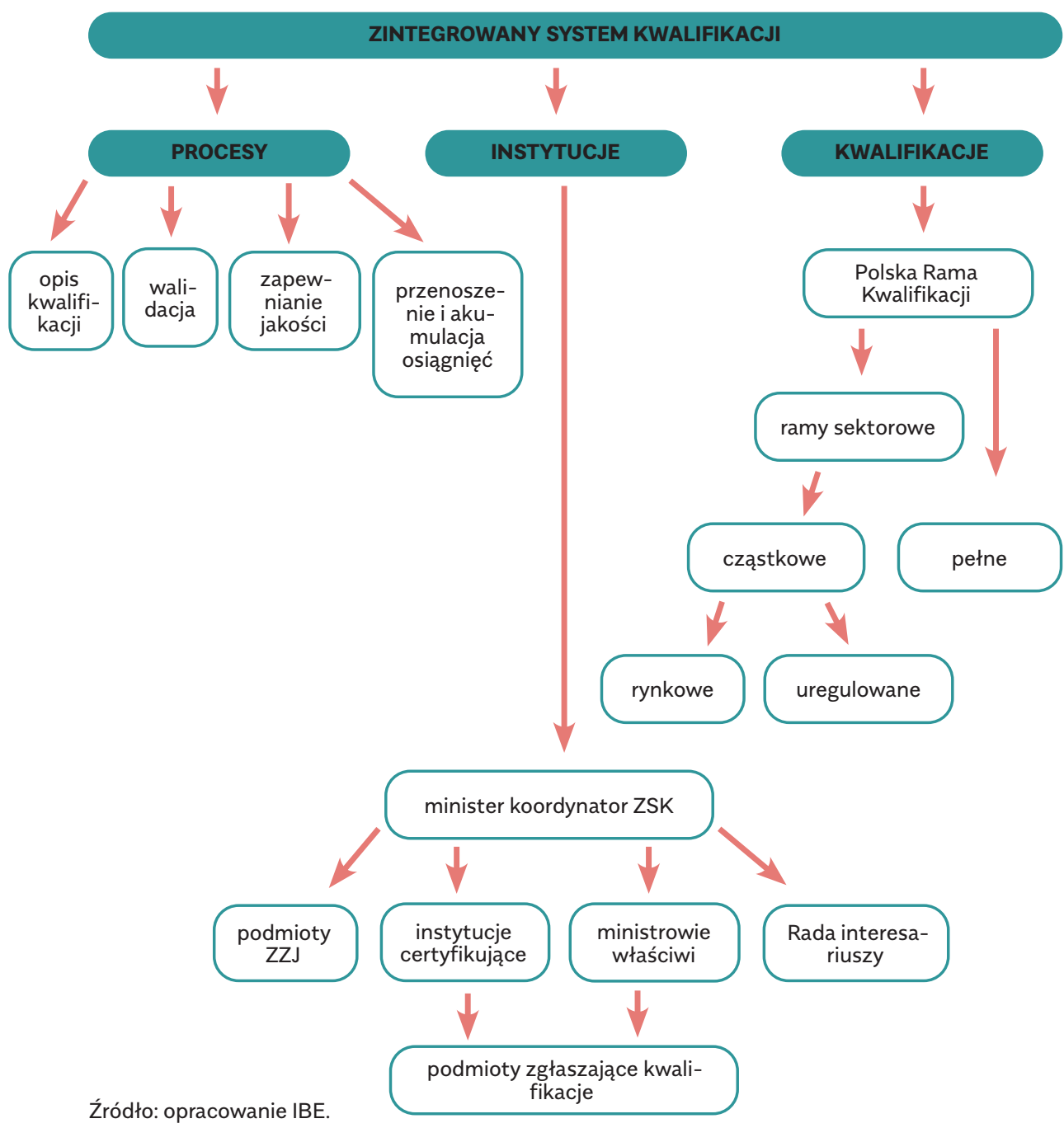




\section{Od efektów uczenia się do kwalifikacji: Polska Rama} Kwalifikacji i Zintegrowany Rejestr Kwalifikacji (ZRK)

Punkt odniesienia dla wszystkich mechanizmów i narzędzi składających się na Zintegrowany System Kwalifikacji stanowią efekty uczenia się. Efekty uczenia się coraz częściej wpływają na definiowanie i opisywanie kwalifikacji oraz programów nauczania, a także na proces oceniania, nauczania i szkolenia.

Podejście to po raz pierwszy sformułowano explicite w europejskich dokumentach strategicznych w 2003 r. i od tego czasu jest ono systematycznie promowane w agendzie politycznej UE na rzecz edukacji, szkoleń i zatrudnienia. Rozwiązanie oparte na efektach uczenia się stosowane było w niektórych państwach europejskich znacznie wcześniej, czego przykładem są reformy w Wielkiej Brytanii i Finlandii w latach 80. i 90. W Polsce zmiany w kierunku dostosowania istniejących rozwiązań do systemu opartego na efektach uczenia się rozpoczęły się w 2008 r., kiedy to programy nauczania zaczęły być definiowane w języku efektów uczenia się. Znacząca reforma podstaw programowych kształcenia w zawodach zakończona w 2012 r. polegała m.in. na przełożeniu jej na język efektów uczenia się. W 2012 r. wprowadzono także zmiany w zakresie egzaminów czeladniczych i mistrzowskich przeprowadzanych przez komisje egzaminacyjne izb rzemieślniczych (Sławiński i in. 2013).

Zalecenie Parlamentu Europejskiego i Rady z dnia 22 maja 2017 r. w sprawie europejskich ram kwalifikacji dla uczenia się przez całe życie definiuje efekty uczenia się jako "określenie tego, co uczący wie, rozumie i potrafi wykonać po ukończeniu procesu uczenia się, dokonywane w kategoriach wiedzy, umiejętności oraz odpowiedzialności i autonomii" (Zalecenie Rady... 2017). Z kolei ustawa o ZSK definiuje efekty uczenia się jako "wiedzę, umiejętności oraz kompetencje społeczne nabyte w procesie uczenia się" 6 . W opublikowanym w 2017 r. przez Instytut Badań Edukacyjnych (IBE) Słowniku Zintegrowanego Systemu Kwalifikacji poza powyższymi definicjami znaleźć można bardziej potoczne, opisowe objaśnienie terminu efektów uczenia się: „Używając potocznego języka, można to pojęcie wyjaśnić następująco: na efekty uczenia się składa się to, co człowiek wie i rozumie, co potrafi wykonać, a także to, do jakich zobowiązań jest przygotowany. Poszczególne efekty 
uczenia się mogą mieć charakter specyficzny dla danej kwalifikacji lub uniwersalny; mogą np. odnosić się do tzw. kompetencji kluczowych lub ogólnozawodowych" (Sławiński 2017, s. 17).

Objaśnione powyżej podejście oparte na efektach uczenia się jest wykorzystywane do wielu różnych celów, z których najważniejsze to:

$\rightarrow$ ramy kwalifikacji i zawarte w nich charakterystyki poziomów,

$\rightarrow$ standardy kwalifikacji,

$\rightarrow$ programy nauczania,

$\rightarrow$ systemy oceny i walidacji,

$\rightarrow$ zapewnienie jakości,

$\rightarrow$ nauczanie i szkolenie.

W odniesieniu do wszystkich tych celów podejście to w centrum procesu stawia osobę uczącą się oraz poziom wiedzy, umiejętności i kompetencji, które ma ona osiągnąć. Równoważy też tradycyjny nacisk na kształcenie i szkolenie, w szczególności na czas jego trwania i miejsce uczenia się (Defining, writing and applying... 2017, s. 17).

Charakterystyki kolejnych poziomów ramy kwalifikacji wskazują, w jaki sposób złożoność efektów uczenia się wzrasta z poziomu na poziom. W PRK, podobnie jak w Europejskiej Ramie Kwalifikacji (ERK), wyróżnia się osiem poziomów kwalifikacji. Charakterystyki poziomów PRK odnoszą się do pełnego spektrum wymaganych dla kwalifikacji efektów uczenia się, to znaczy do wiedzy, umiejętności oraz kompetencji społecznych. Charakterystyki kolejnych poziomów PRK odzwierciedlają coraz wyższe wymagania w tych zakresach.

Unikatowym polskim rozwiązaniem są dwustopniowe charakterystyki poziomów w PRK. Charakterystyki poziomów pierwszego stopnia (uniwersalne) dotyczą wszystkich rodzajów edukacji.

Charakterystyki poziomów pierwszego i drugiego stopnia należy czytać łącznie, co oznacza, że charakterystyki drugiego poziomu stanowią uszczegółowienie oraz rozwinięcie charakterystyk pierwszego poziomu (Chłoń-Domińczak i in. 2017, s. 4). 
Rysunek 2. Schemat Polskiej Ramy Kwalifikacji

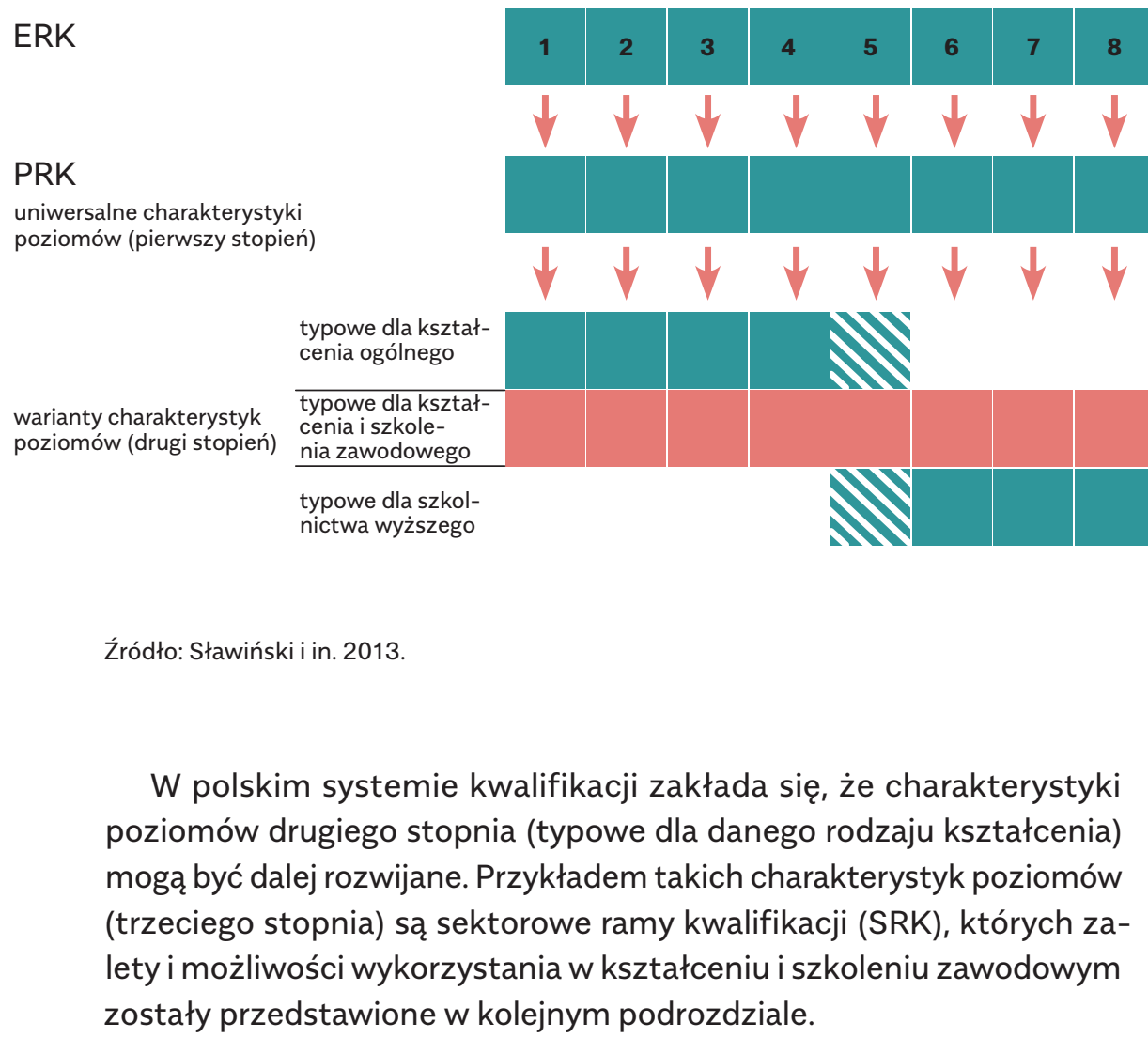


Rysunek 3. Schemat zależności między Europejską i Polską

Ramą Kwalifikacji a Sektorowymi Ramami Kwalifikacji

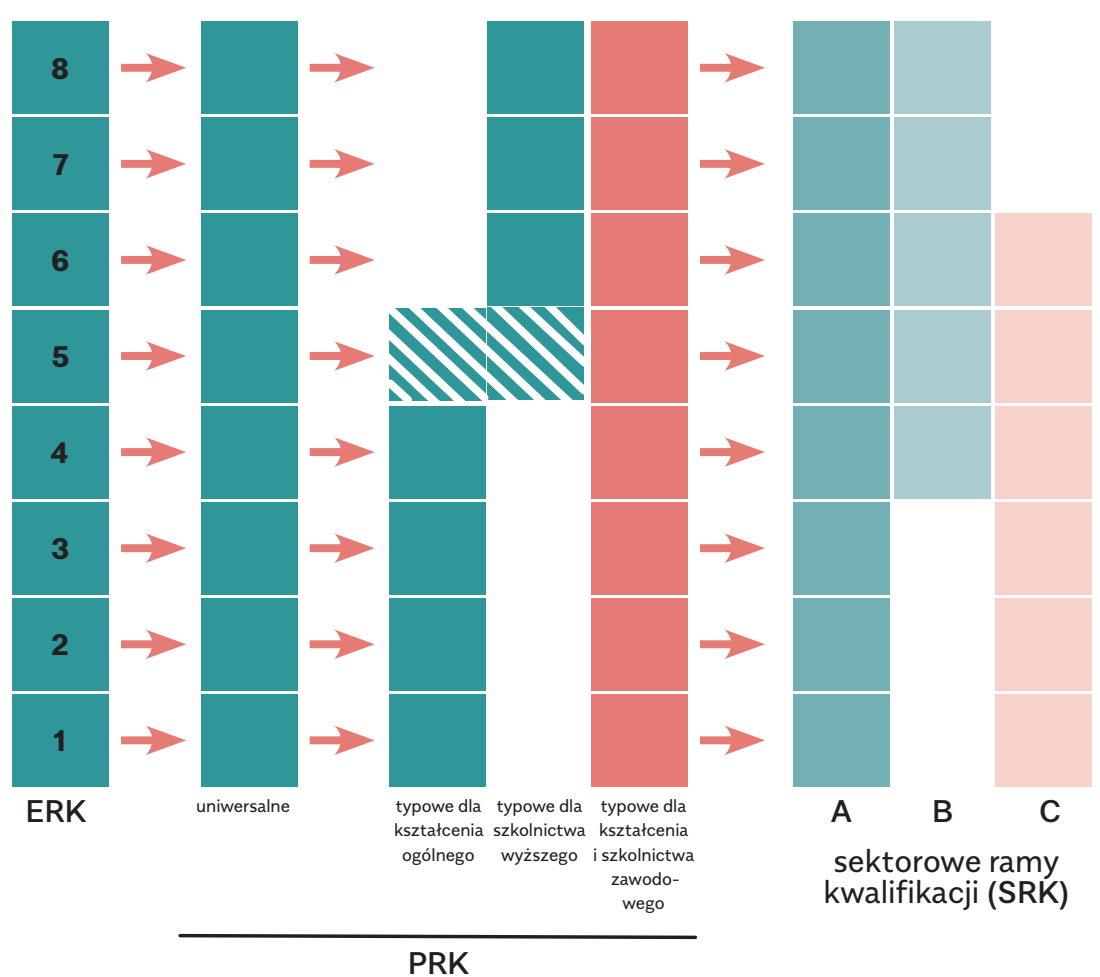

Źródło: opracowanie IBE.

Jak wspomniano wcześniej, drugim całkowicie nowym narzędziem systemowym określonym w ustawie o ZSK jest Zintegrowany Rejestr Kwalifikacji (ZRK). Wszystkie kwalifikacje, które się w nim znajdują, muszą zostać opisane w sposób określony w ustawie o ZSK. Każdej z nich musi także zostać przypisany jeden z ośmiu poziomów Polskiej Ramy Kwalifikacji (a w przypadku kwalifikacji branżowych może to być dodatkowo numer poziomu Sektorowej Ramy Kwalifikacji) ${ }^{7}$.

$7 \quad$ Zgodnie z ustawą o ZSK kwalifikację rynkową odnosi się dodatkowo do poziomu sektorowej ramy kwalifikacji, jeśli ustanowiono sektorową ramę kwalifikacji w danym sektorze lub branży. 
Rejestr został uruchomiony w sierpniu 2016 r., a od stycznia 2018 r. jego prowadzenie i rozwój zostały powierzone Instytutowi Badań Edukacyjnych. ZRK jest rejestrem publicznym, ewidencjonuje wszystkie kwalifikacje włączone do ZSK spełniające wymagania określone w ustawie o ZSK, zarówno kwalifikacje nadawane w obszarach oświaty (np. dyplom technika, świadectwo maturalne) i szkolnictwa wyższego (np. tytuł magistra, doktora), jak i kwalifikacje uregulowane przepisami prawa (np. nurek) oraz rynkowe (nadawane po ukończeniu różnego rodzaju kursów i szkoleń). ZRK odgrywa rolę szczególnego rodzaju łącznika integrującego podsystemy kwalifikacji funkcjonujące dotychczas autonomicznie.

Rejestr gromadzi i udostępnia informacje nie tylko o wymaganych dla danej kwalifikacji efektach uczenia się, ale także o instytucjach, które uzyskały prawo do ich nadawania (certyfikowania), oraz o podmiotach, które czuwają nad jakością i wiarygodnością procesów związanych z przyznawaniem kwalifikacji. Jedną z głównych cech Rejestru jest aktualność gromadzonych informacji.

Rodzaje kwalifikacji, które mogą być włączone do ZSK i znaleźć się w ZRK, określa ustawa o ZSK.

Rysunek 4. Rodzaje kwalifikacji w Zintegrowanym Systemie Kwalifikacji

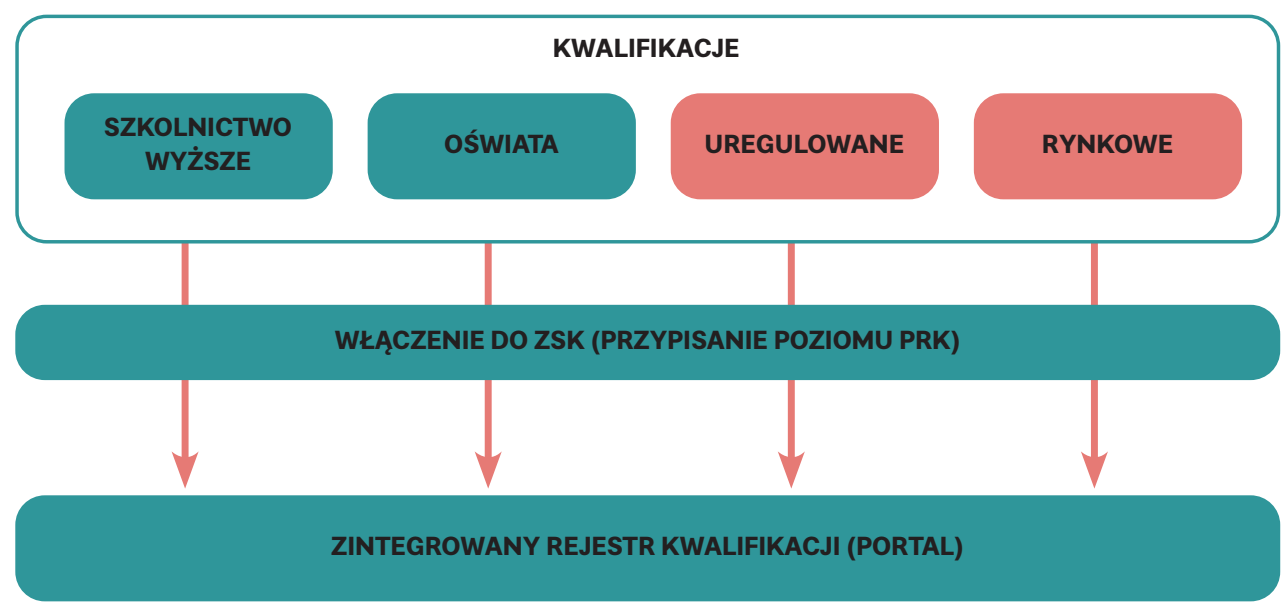

Źródło: opracowanie IBE. 
W ZSK wyróżniono dwa rodzaje kwalifikacji: pełne i cząstkowe. Wszystkie kwalifikacje pełne zostały wymienione w ustawie. Do ZSK włączono z mocy prawa wszystkie kwalifikacje pełne nadawane w oświacie oraz w szkolnictwie wyższym, a także kwalifikacje wyodrębnione w zawodach szkolnych. Kwalifikacjom pełnym poziom PRK przypisano w ustawie. Kwalifikacje nadawane w oświacie i szkolnictwie wyższym (zarówno pełne, jak i cząstkowe) nazywane są często potocznie "kwalifikacjami formalnymi”, gdyż nadawane są w ramach edukacji

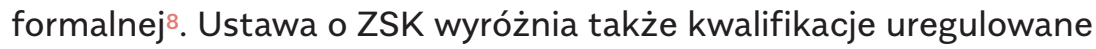
i rynkowe, które są kwalifikacjami cząstkowymi. Kwalifikacje uregulowane to takie, dla których wymagania oraz zasady ich nadawania zostały określone w innych aktach prawnych niż Ustawa o systemie oświaty i Prawo o szkolnictwie wyższym. Kwalifikacje te występują we wszystkich dziedzinach działalności. Dla kwalifikacji uregulowanych ustawa określiła ogólne standardy i zasady, na jakich mogą one być włączone do ZSK. Kwalifikacje, które nie mają umocowania w powszechnie obowiązującym prawie, są w ustawie o ZSK określone jako kwalifikacje rynkowe. Ustawa daje możliwość włączenia kwalifikacji rynkowej do ZSK, o ile odpowiada ona określonym wymaganiom.

Kwalifikacje rynkowe, podobnie jak uregulowane, mogą funkcjonować bez włączania ich do ZSK. To właśnie kwalifikacje rynkowe i zasady ich tworzenia, nadawania i włączania do ZSK stanowią o znaczącej systemowej zmianie w podejściu do edukacji pozaformalnej.

Kwalifikacje rynkowe są wypracowywane przez różne środowiska (organizacje społeczne, zrzeszenia, korporacje lub inne podmioty) na podstawie zgromadzonych przez nie doświadczeń. Wyraz "rynkowe” oznacza w tym przypadku, że kwalifikacje te powstały i funkcjonują na "wolnym rynku” kwalifikacji. Mogą one dotyczyć działalności o charakterze ściśle zawodowym, ale również różnych obszarów działalności społecznej, w tym wychowawczej i opiekuńczej, a także działalności

Ustawa o ZSK definiuje edukację formalną jako kształcenie realizowane przez publiczne i niepubliczne szkoły oraz inne podmioty systemu oświaty, uczelnie oraz inne podmioty systemu szkolnictwa wyższego, w ramach programów, które prowadzą do uzyskania kwalifikacji pełnych, kwalifikacji nadawanych po ukończeniu studiów podyplomowych, o których mowa w art. 2 ust. 1 pkt 11 Ustawy z dnia 27 lipca 2005 r. - Prawo o szkolnictwie wyższym (Dz.U. 2012 poz. 572 z późn. zm. 1), albo kwalifikacji w zawodzie, o której mowa w art. 10 ust. 3 pkt 1 Ustawy z dnia 7 września 1991 r. o systemie oświaty (Dz.U. 2015 poz. 2156 oraz Dz.U. 2016 poz. 35). 
o charakterze rekreacyjnym. O włączeniu decyduje minister właściwy dla kwalifikacji w odpowiedzi na inicjatywę zainteresowanego środowiska (Sławiński 2017, s. 35). Wieloetapowy proces związany z włączaniem kwalifikacji rynkowych do ZSK w założeniu ma na celu poprawę jakości tych kwalifikacji i poprzez zwiększenie poziomu ich wiarygodności ma wpłynąć na podniesienie liczby Polaków decydujących się na rozwijanie swoich kompetencji i zdobywanie kolejnych kwalifikacji stanowiących uzupełnienie kształcenia podejmowanego w systemie formalnym.

W tej chwili (listopad 2018 r.) w ZRK dostępne są kwalifikacje pełne, tj. te, które zdobywa się w systemie oświaty lub szkolnictwa wyższego, oraz jedenaście kwalifikacji z rzemiosła i sześć kwalifikacji rynkowych. Około stu kwalifikacji rynkowych znajduje się na różnych etapach procedury włączenia ich do ZSK i tym samym do ZRK?.

\section{Branżowy kontekst Zintegrowanego Systemu} Kwalifikacji - sektorowe ramy kwalifikacji jako narzędzie wspierania kształcenia i szkolenia zawodowego

Zintegrowany System Kwalifikacji wraz z jego narzędziami i regulacjami opisanymi w ustawie o ZSK daje szczególne możliwości, jeśli chodzi o tzw. sektorowe czy też branżowe podejście do tworzenia i nadawania kwalifikacji funkcjonujących na polskim rynku pracy.

Wskazuje się (Tutschner et al. 2008) na wiele zalet przyjęcia podejścia sektorowego w odniesieniu do kompetencji i kwalifikacji, m.in. ze względu na to, że przy jego zastosowaniu:

$\rightarrow$ struktury sektorowe są łatwo identyfikowalne i podobne w całej Europie,

$\rightarrow$ dyskusje o narzędziach takich jak ECTS, ECVET i ramy kwalifikacji mogą być prowadzone przy użyciu jednoznacznego i zrozumiałego dla wszystkich stron języka,

$\rightarrow$ partnerzy społeczni są angażowani do debaty o kompetencjach na poziomie sektorowym, co z kolei jest podstawą do zorganizowania dialogu społecznego w zakresie edukacji zawodowej (Żurawski i in. 2018, s. 11).

$9 \quad$ Zintegrowany Rejestr Kwalifikacji jest dostępny za pośrednictwem portali rejestr.kwalifikacje. gov.pl oraz kwalifikacje.gov.pl. 
Doświadczenia krajowe i zagraniczne wskazują, że powodzenie SRK w konkretnej branży, tj. odpowiednie (adekwatne) sformułowanie charakterystyk opisu, ich użyteczność i wykorzystywanie przez środowisko branżowe, uzależnione jest wprost od stopnia udziału przedstawicieli środowiska na etapie konstruowania tego narzędzia. Sektorowa Rama Kwalifikacji zaakceptowana przez branżę to wspólna platforma pozwalająca na kształtowanie branżowego systemu kwalifikacji w zakresie tworzenia programów szkoleniowych, walidacji efektów uczenia się, porównywania kwalifikacji, tworzenia ścieżek rozwoju kariery i rekrutacji.

W krajach, w których SRK zostały bezpośrednio odniesione do krajowej ramy kwalifikacji i tym samym do ERK ( $w$ tym w Polsce), obserwuje się większe zrozumienie dla tych rozwiązań i akceptację wśród interesariuszy. Istnieją takie kraje i branże (np. sektor morski w Danii), w których SRK wyprzedziły o kilka lat Zalecenie Parlamentu Europejskiego i Rady z dnia 23 kwietnia 2008 r. w sprawie ustanowienia europejskich ram kwalifikacji dla uczenia się przez całe życie. Ich utworzenie stanowiło rodzaj forpoczty i przygotowania gruntu dla rozwiązań europejskich. Istnieją również kraje, w których SRK funkcjonują oprócz krajowych ram kwalifikacji przyjętych na szczeblu centralnym. Przykładem może być tutaj sektorowa rama dla branży motoryzacyjnej w Niemczech. Analiza funkcjonujących w Europie SRK pozwala wyodrębnić kilka łączących je cech, które można określić jako ich cechy konstytutywne. Są to przede wszystkim: wysokie zaangażowanie interesariuszy w ich tworzenie i funkcjonowanie, skoncentrowanie na efektach uczenia się wywiedzionych ze środowiska pracy danej branży, oparcie na nich mechanizmów kształtowania branżowego systemu kwalifikacji, tj. zapewniania jakości kwalifikacji, w tym walidacji, oraz wpływu na poprawę przejrzystości i porównywalności kwalifikacji branżowych. 
Rozwiązania systemowe...
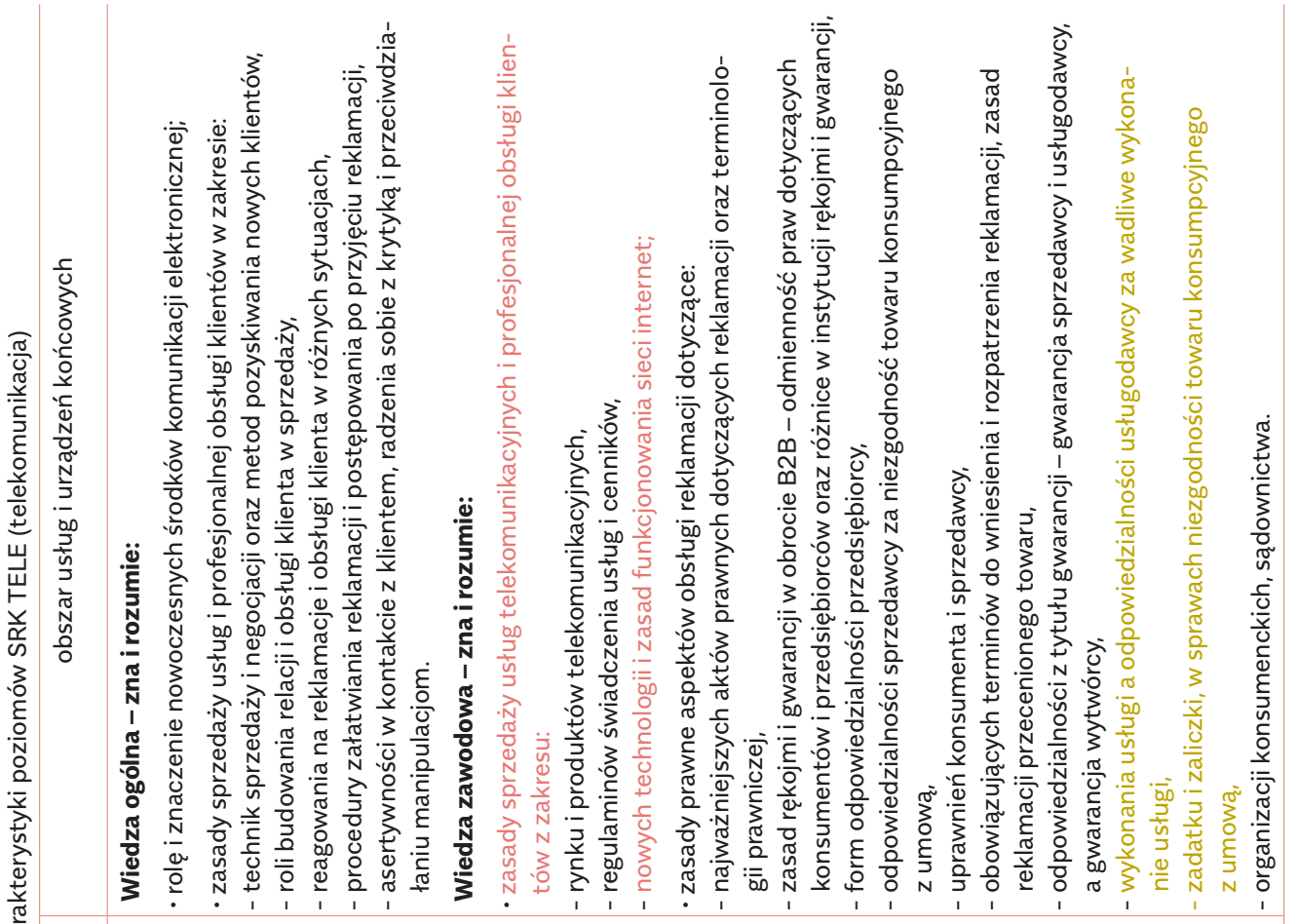

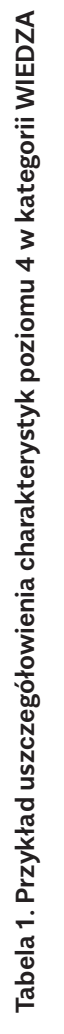

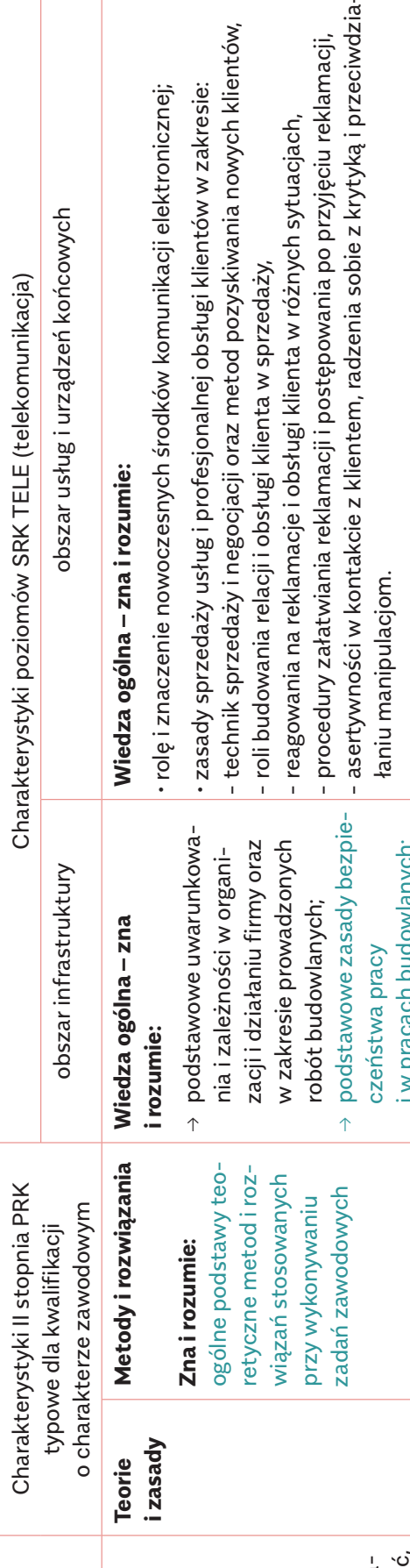

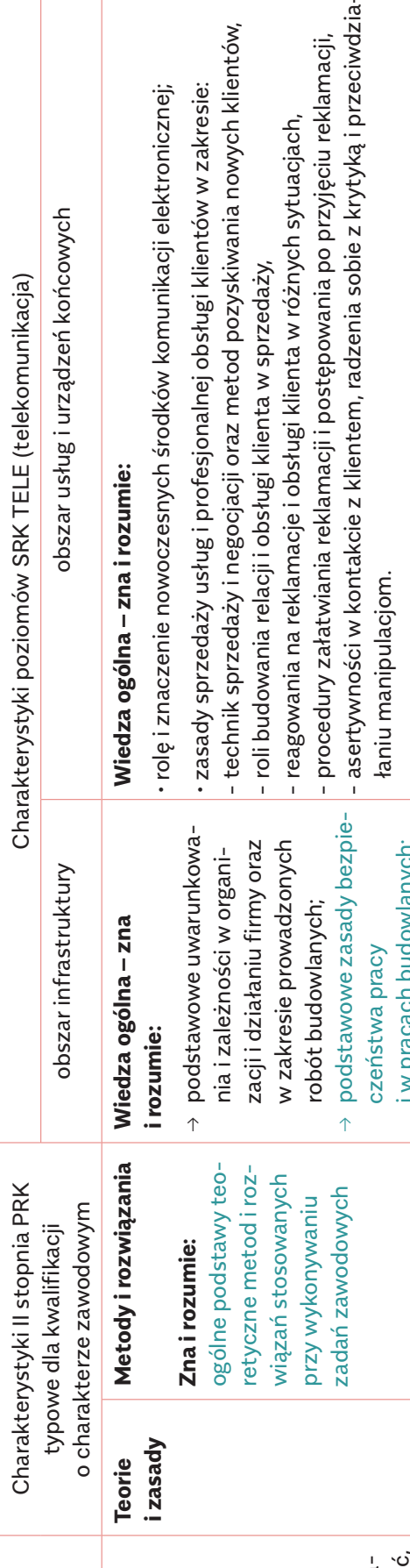
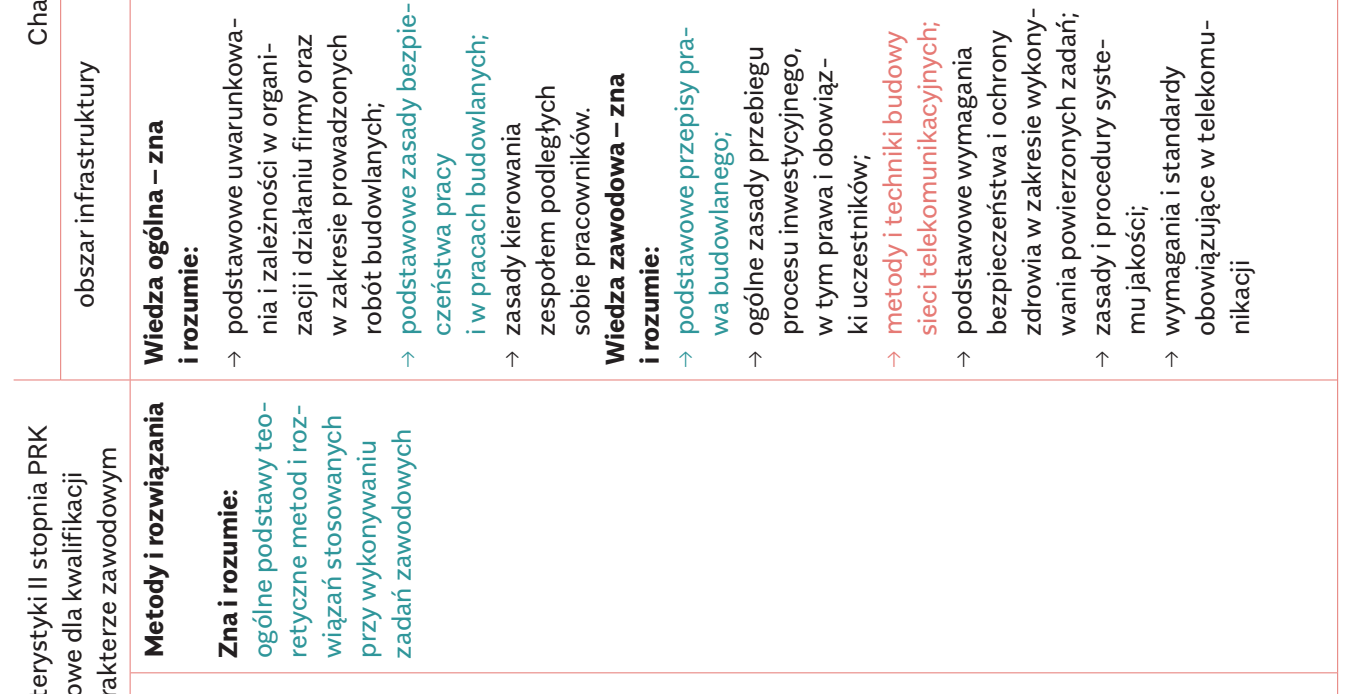

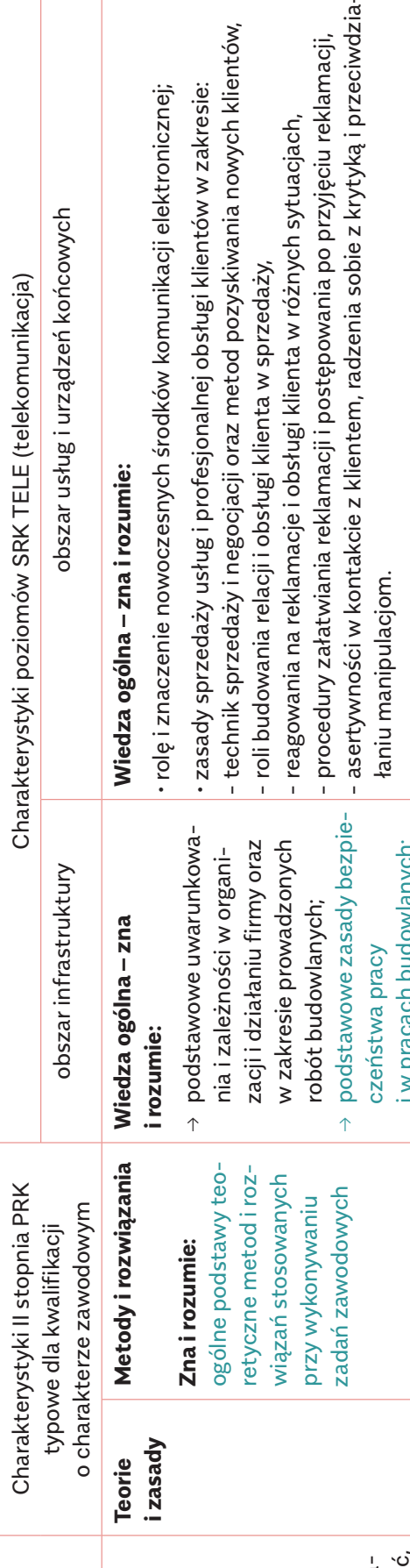

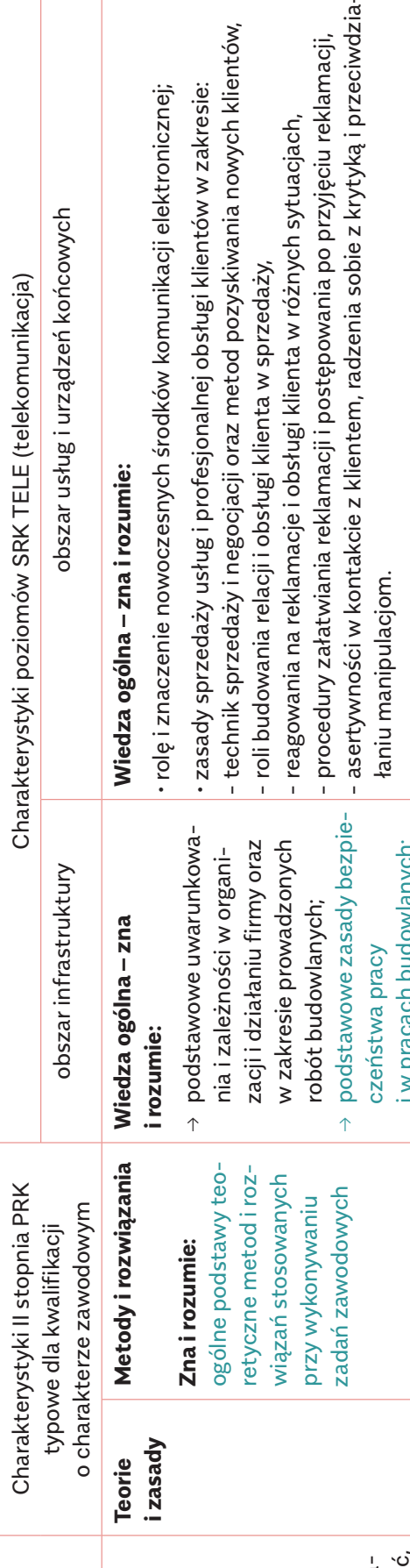

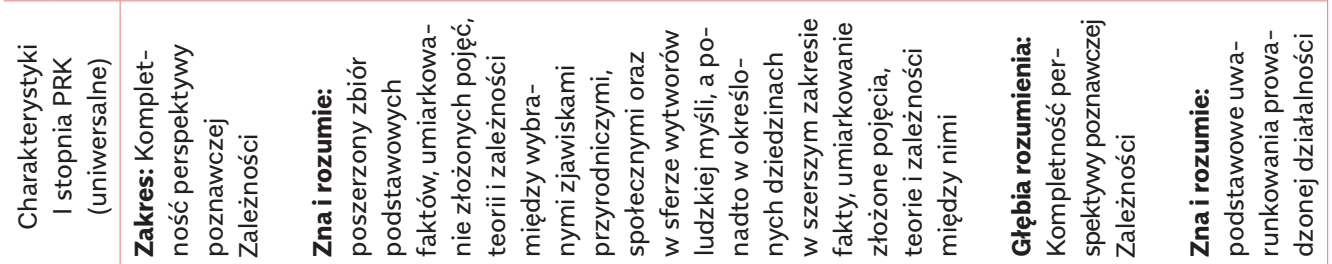




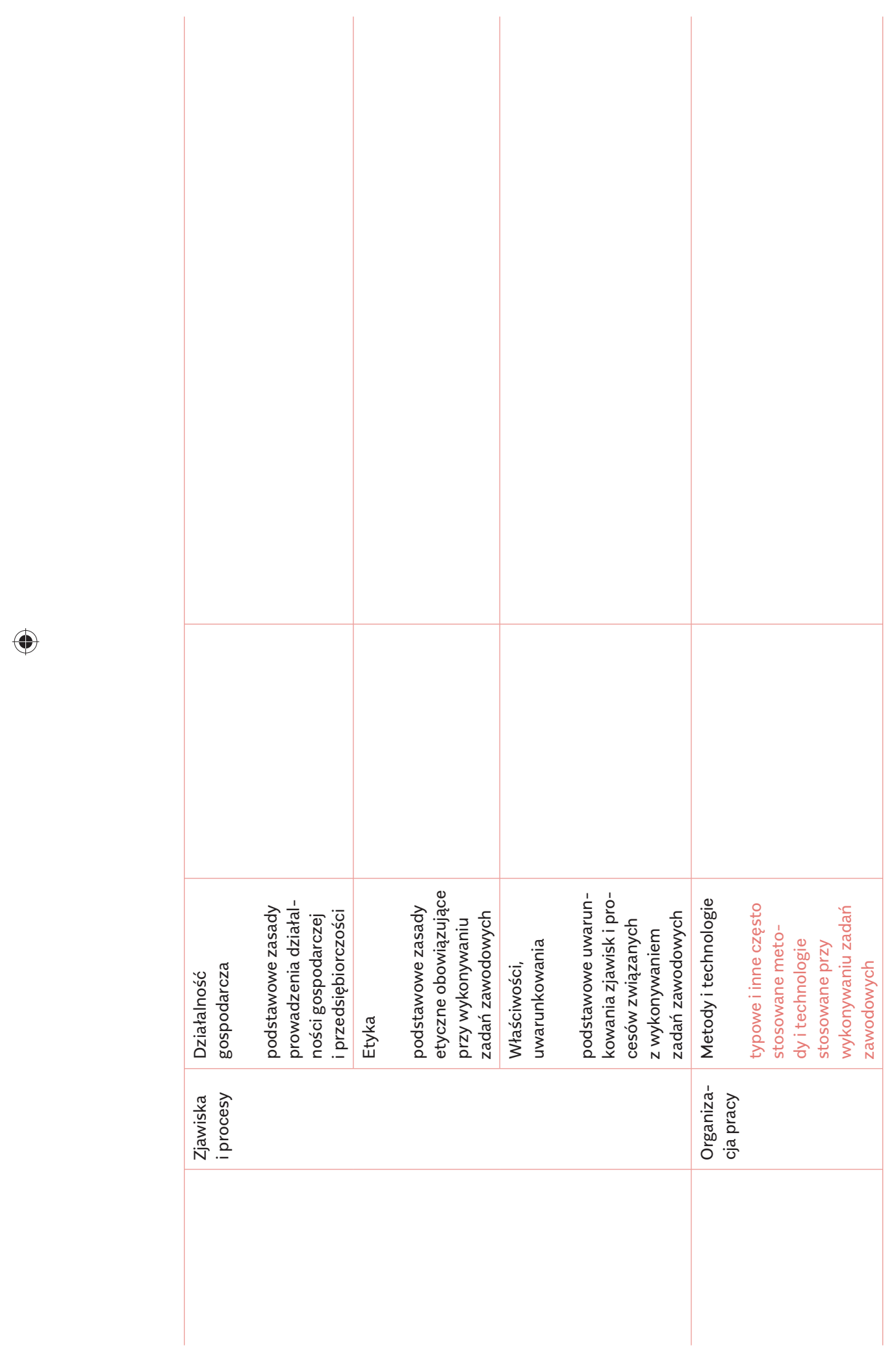



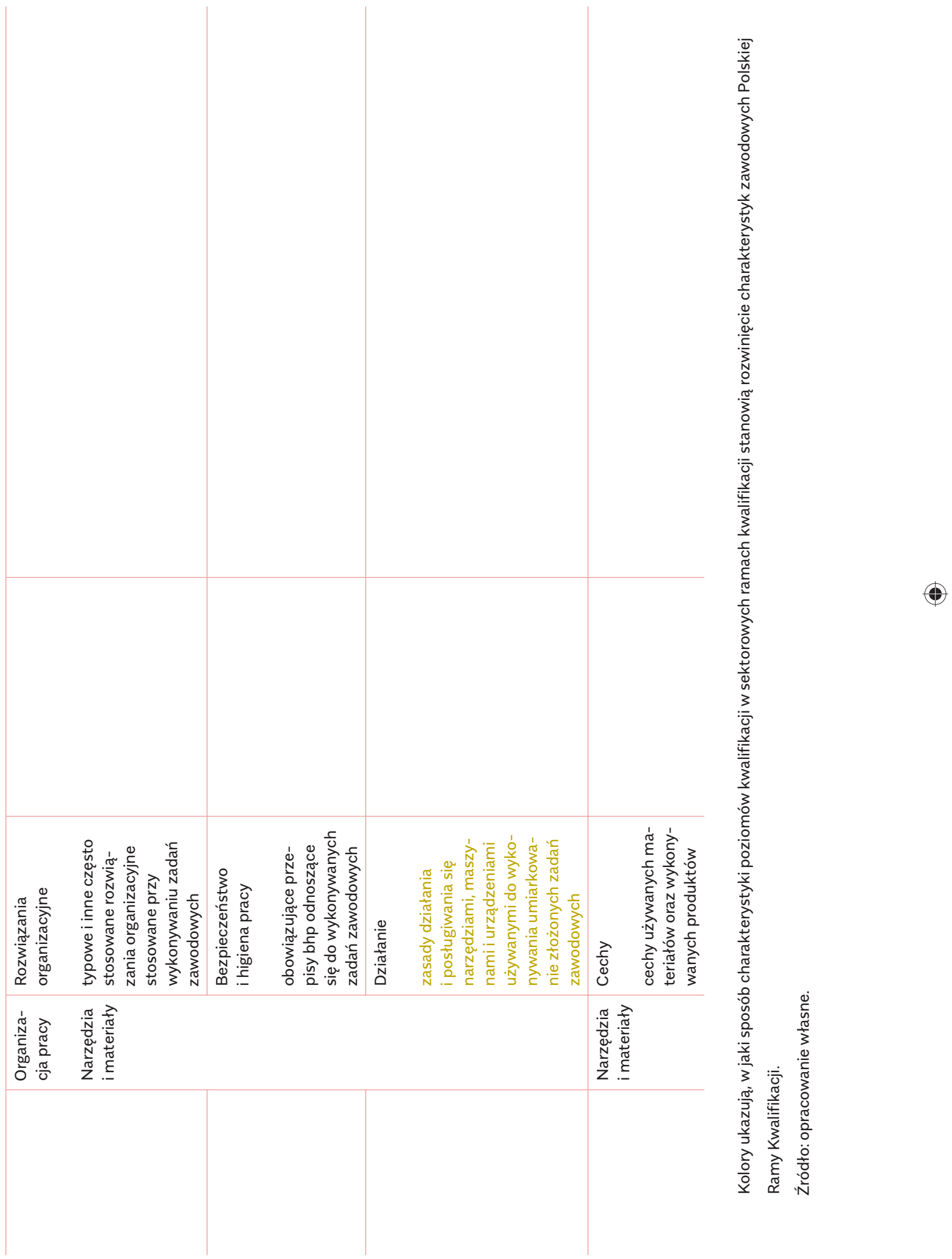
Ustawa o ZSK definiuje sektorową ramę kwalifikacji jako "opis poziomów kwalifikacji funkcjonujących w danym sektorze lub branży; poziomy Sektorowych Ram Kwalifikacji odpowiadają odpowiednim poziomom Polskiej Ramy Kwalifikacji". Artykuł 11 ust. 1 tej samej Ustawy precyzuje, że są one "rozwinięciem wybranych charakterystyk poziomów PRK typowych dla kwalifikacji o charakterze zawodowym". Charakterystyki poziomów kwalifikacji w sektorowych ramach stanowią rozwinięcie charakterystyk uniwersalnych i zawodowych PRK. W rzadszych, uzasadnionych przypadkach mogą też nawiązywać do innych charakterystyk PRK, zwykle typowych dla szkolnictwa wyższego. Charakterystyki poziomów w sektorowych ramach kwalifikacji uwzględniają efekty uczenia się specyficzne dla danej branży, dzięki czemu mogą uwypuklić kwestie nieuwzględnione w PRK (tabela 1). Sektorowe Ramy Kwalifikacji z założenia tworzone są tylko w tych sektorach czy branżach, w których pojawia się zainteresowanie stworzeniem takiego narzędzia. Najczęściej wynika ono z niedopasowania edukacji do potrzeb rynku pracy dla danej branży. Długotrwałe problemy ze znalezieniem pracowników lub też brak potrzebnych w branży kompetencji skłaniają przedstawicieli sektora do inicjatyw w obszarze edukacji zawodowej, kompetencji i kwalifikacji sektorowych. Jedną z nich może być właśnie rama sektorowa definiująca i porządkująca kompetencje branżowe. Od 2013 do połowy 2017 r. powstało dziewięć projektów SRK w sektorach: bankowość, telekomunikacja, sport, turystyka, IT, budownictwo, usługi rozwojowe oraz przemysł mody. Aktualnie toczą się prace nad kolejnymi SRK w sektorach zdrowia, handlu i motoryzacji.

Jedno z kluczowych założeń leżących u podstaw prac nad SRK określane jest w skrócie jako "branża dla branży". Oznacza ono, że SRK mają być narzędziem możliwym do praktycznego wykorzystania przez interesariuszy danego sektora, nie zaś wyłącznie eksperckim i czysto teoretycznym opracowaniem, stworzonym przez osoby pracujące nad systemem kwalifikacji. Realizacja tego zamierzenia możliwa jest tylko wtedy, gdy na każdym etapie prac nad SRK uczestniczą w nich aktywnie reprezentanci danego sektora/branży. Tworzenie wszystkich wymienionych wyżej SRK powierzone było zespołom eksperckim reprezentującym najważniejsze typy instytucji funkcjonujące w danym sektorze: 
$\rightarrow$ organizacje branżowe, izby gospodarcze;

$\rightarrow$ pracodawców - różne typy przedsiębiorstw o zróżnicowanej wielkości (mikro, małe, średnie, duże) i strukturze organizacyjnej, w tym także organizacje lub stowarzyszenia pracodawców;

$\rightarrow$ instytucje edukacyjne - działające zarówno w systemie edukacji formalnej (oświata i szkolnictwo wyższe), jak i pozaformalnej (komercyjne firmy szkoleniowe, ale również stowarzyszenia i związki branżowe organizujące kursy i szkolenia, w tym w szczególności - tam gdzie dotyczy - izby rzemieślnicze);

$\rightarrow$ instytucje pełniące funkcje nadzoru lub regulacyjne (jeśli dotyczy);

$\rightarrow$ instytucje publiczne, w szczególności samorządy terytorialne;

$\rightarrow$ organizacje pracowników, zwłaszcza związki zawodowe;

$\rightarrow$ inne instytucje, jeśli są właściwe dla danego sektora.

W przypadku pracodawców bardzo istotne było dokonanie rozeznania w zakresie głównych obszarów biznesu (obszarów funkcjonalnych) w sektorze/branży (przykładowo w sektorze bankowym są to np.: obszar compliance, controlling, bankowość detaliczna i korporacyjna, ryzyko itd.; w turystyce: hotelarstwo, gastronomia, organizacja turystyki, pilotaż itd.). Dobierając członków zespołu eksperckiego opracowującego SRK, dużą wagę przywiązywano do tego, by znaleźli się w nim przedstawiciele wszystkich ważnych w kontekście danego sektora typów instytucji oraz - w przypadku pracodawców - przedstawiciele każdego ze zidentyfikowanych istotnych obszarów biznesu (funkcjonalnych).

Gotowe projekty SRK za każdym razem skonsultowane były w szerokim gronie interesariuszy danego sektora/branży za pomocą kwestionariuszy ankiet, wywiadów indywidualnych i seminariów konsultacyjnych (Żurawski i in. 2018).

Zaprezentowany $\mathrm{w}$ tabeli 4 przykład charakterystyk PRK poziomu 4. w kategorii "wiedza” na kolejnych poziomach szczegółowości w odniesieniu do zawodowych i branżowych efektów uczenia się ma za zadanie ukazać istotę budowy PRK oraz możliwości, które ze sobą niesie. W ostatniej kolumnie, przedstawiającej charakterystyki SRK poziomu 4. dla branży telekomunikacyjnej, widać rozróżnienie na dwa obszary: obszar infrastruktury oraz obszar usług i urządzeń końcowych. Podziału tego dokonali przedstawiciele branży telekomunikacyjnej tworzący sektorową ramę. Uznali oni, że to właśnie te dwa obszary są cha- 
rakterystyczne w odniesieniu do kompetencji branżowych, które należy wyszczególnić jako odróżniające sektor telekomunikacji od innych sektorów. $Z$ tego względu dla każdego z obszarów sformułowano osobne charakterystyki poziomów. Podejście to odzwierciedla wspomniane powyżej jedno $z$ dwóch głównych założeń tworzenia sektorowych ram kwalifikacji, którym jest zaangażowanie przedstawicieli branży w tworzenie tego narzędzia na wszystkich etapach jego powstawania.

Drugim założeniem SRK jest zastosowanie ich w porządkowaniu kwalifikacji nadawanych w systemie pozaformalnym, dla których punktem odniesienia są właśnie charakterystyki PRK typowe dla kwalifikacji o charakterze zawodowym. W tabeli 1 tymi samymi kolorami zaznaczono wiązki efektów uczenia się o charakterystykach typowych dla kształcenia zawodowego i ich rozwinięcie (doprecyzowanie) w odniesieniu do efektów uczenia się typowych dla branży telekomunikacyjnej. Na tym przykładzie widać, w jaki sposób ogólne charakterystyki PRK przekładane są na język konkretnej branży.

Rama sektorowa porządkuje kompetencje w branży, przyspiesza proces opracowywania i włączania kwalifikacji branżowych do ZSK. SRK może ułatwić określanie poziomów PRK dla kwalifikacji. Każda kwalifikacja składa się z efektów uczenia się, którym można przyporządkować konkretne poziomy PRK. Takie przyporządkowanie jest łatwiejsze, jeśli do efektu uczenia się z jakiejś kwalifikacji przyrównamy charakterystykę poziomu sprofilowaną branżowo. Kwalifikacja może składać się z efektów uczenia się uplasowanych na różnych poziomach, a o jej ostatecznym poziomie w PRK decyduje to, jaki poziom ma większość efektów dla tej kwalifikacji kluczowych.

Sektorowa rama kwalifikacji może także być wykorzystana na poziomie przedsiębiorstwa, w zarządzaniu zasobami ludzkimi czy kompetencjami. Obecnie trwają prace mające na celu dokładne określenie możliwości wykorzystania ram sektorowych (tzw. pilotaże w przedsiębiorstwach) w firmach. Działania dokonane w sektorze telekomunikacji wskazują, że możliwe jest wykorzystanie języka ram sektorowych łączącego język efektów uczenia się z terminologią branżową do opisu stanowisk pracy oraz w ramach rekrutacji i selekcji kandydatów. Ramy sektorowe mają ułatwić dopasowanie kompetencji posiadanych przez pracowników do potrzeb rynku pracy, umożliwić potwierdzenie ich rzeczywistych umiejętności, w szczególności jeśli zostały one uzyskane poza edukacją formalną. Z perspektywy pracownika może to przyczynić 
się do szybszego znalezienia pracy, jej utrzymania lub zmiany, a także sprzyja awansowi zawodowemu (Żurawski i in. 2018).

\section{Podsumowanie}

Przyjęcie w 2015 r. ustawy o Zintegrowanym Systemie Kwalifikacji stanowiło ważny krok w rozwoju polskiego systemu edukacji. Punktem wyjścia dla tych zmian była decyzja o przyjęciu przez Polskę zalecenia Parlamentu Europejskiego (PE) i Rady o stworzeniu Polskiej Ramy Kwalifikacji opartej na Europejskiej Ramie Kwalifikacji. Polska przyjęła założenie, że Polska Rama Kwalifikacji będzie narzędziem reformującym; że przyszły sukces uznania jej na gruncie polskim oraz międzynarodowym za narzędzie wiarygodne uzależniony jest od wprowadzenia wielu rozwiązań i mechanizmów poprawiających jakość polskich kwalifikacji. Założenie to dotyczyło przede wszystkim kwalifikacji nadawanych w systemie edukacji pozaformalnej w ramach różnych struktur, instytucji i organizacji.

W systemach oświaty i szkolnictwa wyższego od lat obowiązują jasno określone zasady zapewniania jakości kwalifikacji wynikające z przepisów prawa. Kwalifikacje nadawane poza tymi systemami funkcjonują na podstawie różnych ustaw lub innych regulacji różnej rangi ustanowionych przez rozmaite podmioty: korporacje zawodowe, organizacje, instytucje szkoleniowe. Cechą charakterystyczną systemu kwalifikacji w Polsce jest stosunkowo duża autonomia poszczególnych podsystemów. Nie zawsze kwalifikacje nadawane w ramach różnych sektorów można do siebie odnosić, przy nadawaniu kwalifikacji rzadko możliwe jest też uwzględnienie kwalifikacji wcześniej nabytej w innym sektorze. Rozpoznawanie i certyfikowanie kompetencji zdobywanych poza zorganizowanymi formami edukacji jest rozproszone. Nie ma pełnej i powszechnie dostępnej informacji, gdzie i jakie kwalifikacje można zdobyć, jakie są wymagania oraz jakie warunki należy spełnić, by określoną kwalifikację uzyskać. Informacje te są dostępne sektorowo lub bezpośrednio w instytucjach nadających kwalifikacje.

Zmodernizowanie krajowego systemu kwalifikacji przez wdrożenie Polskiej Ramy Kwalifikacji i Zintegrowanego Rejestru Kwalifikacji pozwala integrować ten system. Zgodnie z Zaleceniem PE w sprawie ERK do podstawowych założeń Zintegrowanego Systemu Kwalifikacji w Polsce należą: powszechne stosowanie rozwiązań, w których efekty uczenia się są głównym punktem odniesienia, umożliwienie walidowa- 
nia efektów uczenia uzyskanych niezależnie od formy uczenia się (edukacji formalnej, pozaformalnej, uczenia się nieformalnego), rozwijanie możliwości akumulowania i przenoszenia osiągnięć oraz powszechne wdrażanie procedur zapewniania jakości kwalifikacji zgodnie ze standardami przyjętymi w Europie (Sławiński i in. 2013).

Podniesienie jakości procesu nadawania kwalifikacji z systemu pozaformalnego uwiarygadnia na poziomie krajowym i międzynarodowym numer PRK przypisany tym kwalifikacjom. Komunikat skierowany do wszystkich interesariuszy systemu o tym, że dyplom czy certyfikat z nadanym numerem PRK oznacza, iż na wszystkich etapach tworzenia i nadawania tej kwalifikacji jej jakość została zabezpieczona odpowiednimi mechanizmami wewnętrznego i zewnętrznego systemu zapewniania jakości. To powinno wpłynąć na wzrost zaufania do takich kwalifikacji zarówno wśród uczących się, jak i na rynku pracy.

Informacje o wszystkich kwalifikacjach włączonych do ZSK można znaleźć w Zintegrowanym Rejestrze Kwalifikacji. Jedną z głównych jego cech jest aktualność gromadzonych informacji. Rejestr staje się główną platformą informacyjną o kwalifikacjach nadawanych w Polsce. Grupy osób i instytucji potencjalnie zainteresowanych informacjami zawartymi w ZRK to m.in.: pracobiorcy, pracodawcy i ich organizacje, nauczyciele, uczniowie, doradcy zawodowi, osoby poszukujące pracy, instytucje rynku pracy, administracja państwowa, jednostki samorządu terytorialnego, związki zawodowe czy izby gospodarcze ${ }^{10}$.

$\mathrm{Na}$ obecnym etapie wdrażania ustawy o ZSK niewątpliwym wyzwaniem na szczeblu centralnym pozostaje wpisanie narzędzi systemowych, jakimi są m.in Polska Rama Kwalifikacji, Zintegrowany Rejestr Kwalifikacji czy sektorowe ramy kwalifikacji w szerszy obraz rozwiązań systemowych w Polsce. Narzędzia systemowe, takie jak standardy kompetencji zawodowych czy przygotowywany do wdrożenia na gruncie polskim system ESCO, powinny wraz z Polską Ramą Kwalifikacji i Zintegrowanym Rejestrem Kwalifikacji w jasny sposób uzupełniać się wzajemnie, a u podstaw ich upowszechniania i wdrażania powinna leżeć przejrzysta informacja skierowana do potencjalnych użytkowników o funkcji tych narzędzi w szerszym kontekście pozostałych rozwiązań systemowych służących polskim obywatelom. 
